\title{
Geographical variation in the genetic diversity and composition of the endangered Queen Conch Strombus gigas (Mesogastropoda: Strombidae) from Yucatán, México
}

\author{
Ricardo Pérez-Enriquez ${ }^{1}$, Francisco Javier Garcia-Rodriguez ${ }^{1,2}$, Gabriela Mendoza-Carrion ${ }^{1}$ \\ \& Claudia Padilla ${ }^{3}$ \\ 1. Centro de Investigaciones Biológicas del Noroeste (CIBNOR), Mar Bermejo 195, Col. Playa Palo Santa Rita, La Paz, \\ B.C.S. 23090, México; rperez@cibnor.mx \\ 2. Present address: Centro Interdisciplinario de Ciencias Marinas-Instituto Politécnico Nacional (CICIMAR-IPN), Apdo. \\ Postal 592, La Paz, B.C.S. 23090, México; fjgarciar@ipn.mx \\ 3. Centro Regional de Investigación Pesquera Puerto Morelos del INAPESCA, Matamoros No. 7, Puerto Morelos, \\ Quintana Roo, 77580, México; claudiapadilla@prodigy.net.mx
}

\section{Received 04-VI-2010. C Corrected 05-I-2011. Accepted 04-II-2011.}

\begin{abstract}
In Mexico and elsewhere in the Caribbean, the queen conch Strombus gigas is an endangered species. Understanding the genetic connectivity of their populations will support management strategies for long term conservation of the species. Genetic diversity and population differentiation was assessed from samples collected at Banco Chinchorro and Isla Cozumel in the Mexican Caribbean and at Arrecife Alacranes in the Gulf of Mexico. Samples were obtained from the commercial capture at Banco Chinchorro $(n=50)$ and Isla Cozumel $(\mathrm{n}=40)$ on March 2004. On November 2004, a non-invasive method for the Arrecife Alacranes sampling was applied, taking the hemolymph of live animals $(n=65)$ and releasing them to the wild. The mitochondrial DNA variation at two genes (COI and Cyt-b) was analyzed. Genetic diversity at the three locations ranged between 0.55-0.65 in COI and 0.87-0.94 in Cyt-b, showing no bottleneck evidences. A non-significant fixation index $\left(F_{S T}=0.019, \mathrm{p}=0.161\right)$ and a Maximum Parsimony Network tree that did not show particular clades associated with any of the geographical locations, suggested a lack of statistically significant genetic differentiation among populations. Nevertheless, the cline patterns observed in both genetic diversity and haplotypic frequencies from Banco Chinchorro through Arrecife Alacranes, and the larger genetic distance between these locations from those between Isla Cozumel, Banco Chinchorro and Arrecife Alacranes, suggest the possibility of a pattern of isolation-by distance. The role of the main current systems over the potential genetic differences in S. gigas populations along the Mexican Caribbean, and the conservation management of $S$. gigas at these locations as discrete units is discussed. Rev. Biol. Trop. 59 (3): 1115-1126. Epub 2011 September 01.
\end{abstract}

Key words: genetic structure, Strombus gigas, mitochondrial DNA, isolation-by-distance, Caribbean, connectivity.

The queen conch Strombus gigas has been an important fishery resource for several countries along the Caribbean Sea, but it is subjected to different threats (overfishing, poaching, habitat destruction, pollution, etc.). The species is recognized as endangered (CITES 1973) due to low population levels in several parts of the Caribbean (Theile 2001), with specific surveys in Venezuela (Schweizer \& Posada 2006), the
British Virgin Islands (Gore \& Llewellyn 2005) and in other countries as well (Theile 2005, Mateo \& Tejeda 2008, Oxenford et al. 2008). In other areas such as Puerto Rico, poaching has also been pointed as a concern issue (Hernández 2008). In Mexico, where the production has decreased from 321MT in 1999 to 151MT in 2008 (CONAPESCA 2010), a small, quota-based commercial fishing occurs in the 
Marine Protected Areas of Banco Chichorro, an atoll located in the South side of Quintana Roo State, and Isla Cozumel in the North side of the state (Anonymous 2006). Nowadays, all queen conch fishing activity is presently forbidden in the State of Yucatán, including the Marine Protected Area of Arrecife Alacranes (Anonymous 2006).

The study of the genetic structure of benthic marine populations has become essential for proper management strategies, since a population may have subpopulations with distinct biological parameters (Ryman \& Utter 1987). Larval dispersal among benthic species may be extensive, depending on the species' life cycle and ocean dynamics. This may lead to genetic homogenization within the species' range. Because this is not always the case, understanding the connectivity between locations, especially for species within Marine Protected Areas, is a management tool that is extensively used for conservation goals (Perez-Ruzafa et al. 2006). To avoid the introduction of unwanted genetic characters or reducing wild's genetic diversity, the information on population genetic variations is important when stock enhancement programs are to be designed (FAO 1993, Beaumont 2000, Bell et al. 2005).

Some studies on queen conch population genetics based on allozymes have been carried out since the 80s and 90s, when Mitton et al. (1989) and Campton et al. (1992) found that, even though a high gene flow was evident in locations within the Caribbean, populations were not panmictic, since genetic differences occurred between beds located near each other. Morales \& López (2003) observed low genetic differentiation at Andros Island in the Bahamas. Morales (2004) suggested an extensive genetic connectivity throughout the Caribbean. In the Mexican Caribbean, Tello-Cetina et al. (2005) found some genetic differentiation among populations.

Genetic studies with other species in the region near the Mexican coasts are scarce. Silberman et al. (1994) showed broad gene flow in spiny lobster Panulirus argus throughout the Caribbean, explained by this lobster's long larval period ( $\sim 10$ months), with extensive dispersal. Nevertheless, in an analysis of reef fish based on mtDNA, Shulman \& Bermingham (1995) showed that the extension of the larval phase was not essential in defining genetic differentiation patterns.

The use of different genetic markers is often desirable for a better understanding of gene flow. For example, mitochondrial DNA (mtDNA) genes, such as cytochrome oxidase b (cyt-b) and cytochrome oxidase subunit I (COI), give adequate information about genetic structure of benthonic species in the Caribbean (Vollmer \& Palumbi 2007, Díaz Ferguson et al. 2010) and in other regions as well (Santos 2006, Rus et al. 2010). In our study, we determined genetic diversity and composition of three Strombus gigas populations from different Yucatan Peninsula coastal areas, to assess potential gene flow among the three locations.

\section{MATERIALS AND METHODS}

Sampling and DNA extraction: Samples were obtained from three sites off the Yucatan Peninsula, two in the Caribbean: Banco Chichorro (18 $\left.34^{\prime} 10^{\prime \prime} \mathrm{N}-87^{\circ} 18^{\prime} 00^{\prime \prime} \mathrm{W}\right)$ and Isla Cozumel (20³6'30" N-86 50'05” W) and one in the Gulf of Mexico: Arrecife Alacranes $\left(22^{\circ} 22^{\prime} 30^{\prime \prime} \mathrm{N}-89^{\circ} 39^{\prime} 00^{\prime \prime} \mathrm{W}\right)$. Muscle tissue samples of queen conch from Banco Chinchorro and Isla Cozumel $(n=50$ and 40, respectively) were obtained from the commercial fishery in March 2004. Conchs from Banco Chinchorro were obtained inside the reef two km SE of Cayo Centro. Samples from Isla Cozumel were collected near Punta Norte by fishermen equipped with SCUBA. Samples were preserved in $95 \%$ ethanol.

Conchs from Arrecife Alacranes $(n=65)$ were collected in November 2004 at three sites near Isla Pérez by a free diver over $10 \times 100 \mathrm{~m}$ belt transects. Conchs were put in plastic containers and were allowed to relax for $30 \mathrm{~min}$. Afterwards, the operculum of each specimen was manually pulled open to expose the hemolymph-irrigated region of the mantle (bluish area), for a non-invasive sampling following 
Yanick \& Heath (2000); 200-400 $\mu$ L of hemolymph was extracted with a sterile $1-\mathrm{mL}$ insulin syringe. The samples were kept in microcentrifuge tubes containing $1 \mathrm{~mL} 95 \%$ ethanol. All the conchs were returned to the area where they were collected. Anesthetizing resulted non productive as a sampling procedure, since specimens put in a 30ppm MS-222 bath for about 1 h did not relax.

The ethanol-preserved samples (tissue and hemolymph) were transported to the genetics laboratory at CIBNOR, where they were kept at $4^{\circ} \mathrm{C}$ until DNA extraction. DNA extraction was performed following the protocol of Sweijd et al. (1998). DNA concentration was verified by spectrophotometer (SmartSpect 3000 , BIORAD) and adjusted to $70 \mu \mathrm{g} / \mathrm{mL}$.

PCR amplifications of mtDNA genes and sample analysis: Two mtDNA genes were analyzed: cytochrome oxidase subunit I (COI) and cytochrome $b$ (Cyt-b). COI was amplified using the primers reported by Folmer et al. (1994). The PCR reactions were done in volumes of $25 \mu \mathrm{L}$ containing 70ng DNA, $0.2 \mathrm{mM}$ dNTPs, $2 \mathrm{mM} \mathrm{MgCl}_{2}, 0.48 \mathrm{pmol}$ each primer, Taq PCR Buffer 1×, and 0.05 units of Taq polymerase (Invitrogen). Amplification conditions were: initial denaturation $\left(94^{\circ} \mathrm{C}, 2 \mathrm{~min}\right)$, 35 cycles of denaturation $\left(95^{\circ} \mathrm{C}, 1 \mathrm{~min}\right)$, annealing $\left(57^{\circ} \mathrm{C}, 1 \mathrm{~min}\right)$, extension $\left(72^{\circ} \mathrm{C}, 2 \mathrm{~min}\right)$ and a final extension $\left(72^{\circ} \mathrm{C}, 5 \mathrm{~min}\right)$. Products were run by electrophoresis in $1 \%$ agarose gels stained with SybrGold (Invitrogen). The 750 base pairs (bp) size bands obtained with COI of three individuals (one from each location) were extracted from the gel using the Gel Extraction Kit (QIAgen) and then sequenced (Macrogen, Korea).

COI sequences were aligned using Chromas Pro V.1.2 software (Technelysium Pty Ltd) to localize polymorphic sites. The COI region was used for an RFLP analysis by selecting the restriction enzymes that recognized the polymorphic sites, using the "NebCutter" program (http://tools.neb.com/NEBcutter2/http://tools. neb.com/NEBcutter2/index.php). The enzymes used for the analysis were: HaeIII, HpaII and
$B s t$ EII. Digestion reactions were done in $6 \mu \mathrm{L}$ volumes containing enzyme buffer $1 \times, 0.3$ units of restriction enzyme, and milliQ water. Samples were incubated overnight at $37^{\circ} \mathrm{C}$ or for $2 \mathrm{~h}$ at $60^{\circ} \mathrm{C}$. Digestion products were run by electrophoresis in $2 \%$ agarose gels stained with SybrGold. Gels were made visible in a transilluminator (Dark Reader ${ }^{\circledR}$, model DR88M, Clare Chemical) and digitally photographed (Cybershot, Sony). Each banding pattern representing a specific haplotype was given a capital letter. The combination of haplotypes for each endonuclease formed a composite haplotype.

The Cyt-b region was first amplified with the primers reported for the freshwater snail genus Potamopyrgus by Neiman \& Lively (2004), Forward: 5'-TTCTTTATTAGGACTTTGTTTAGG; Reverse: 5'-TTTCACCGTCTCTGTTTAGCC, for which two bands were obtained. The 550-bp band was purified from an agarose gel and sequenced (Macrogen, Korea). A forward primer was designed using the Primer3 software (Rozen \& Skaletsky 2000); this primer (Carac-Cyt-bF: 5'-GATTTTAACTGGTCTTTTTCTTGC) was coupled with the Neiman \& Lively (2004) reverse primer; the amplification resulted in a single 480-bp band. Amplification conditions for all the samples were the same as for COI, with the exception of the annealing temperature which was set at $49^{\circ} \mathrm{C}$. All samples from the three locations were sequenced with the reverse primer and the sequences were edited and aligned using Chromas-Pro software. Useful sequences were obtained for 31 samples from Arrecife Alacranes, 26 from Isla Cozumel and 23 from Banco Chinchorro. Sequences of representative haplotypes were deposited in the GenBank (Accession numbers HQ832643-HQ832670).

Haplotypic diversity $(\mathrm{Hd})$ and nucleotidic diversity (Nd) for the COI gene were calculated with the Restriction Enzyme Analysis Package (REAP) (McElroy et al. 1992). For Cyt-b, Hd and Nd were estimated using Arlequin ver. 3.0 (Excoffier et al. 2005). The $\mathrm{Nd} / \mathrm{Hd}$ proportion within each population was estimated to compare the time needed at each population to produce more divergent haplotypes. For both 
genes, REAP was used to determine whether haplotype heterogeneity among populations was significantly different, using a chi-square test based on Monte Carlo simulations (Roff \& Bentzen 1989). Population differentiation was also estimated by an AMOVA using Arlequin ver. 3.0 (Excoffier et al. 2005). A minimum spanning network based on Cyt-b sequences was constructed to review the genealogical relationship among the different haplotypes as it is implemented in the Network program 4.5.1.0. (available at http://www.fluxus-engineering.com/network_terms.htm). Based on the haplotype frequencies, a COI-RFLP genetic distance neighbor-joining dendrogram was constructed with the Phylip software (Felsenstein 1993) and illustrated with Treeview (Page 1996) to show the genetic relation among locations. The statistical significance of the relation between the genetic and geographic distances (isolation by distance) was assessed using the IBD software (Bohonak 2002). The historical demography patterns were estimated using the mismatch distributions of Cyt-b sequences to compare historical trends occurred among the three sites. Goodness-of-fit between the observed and expected distributions under a sudden expansion model was tested using the sum of square deviations (SSD) as implemented in Arlequin ver 3.0 (Excoffier et al. 2005).

\section{RESULTS}

Depending on the genetic marker, the haplotypic diversity in the three locations showed medium (0.55-0.65 in COI) to high (0.87-0.94 in Cyt-b) values. Both genetic diversity indices (Hd and $\mathrm{Nd}$ ) showed a decreasing pattern from Banco Chinchorro to Arrecife Alacranes (Fig. 1). The $\mathrm{Nd} / \mathrm{Hd}$ proportion showed the same decreasing pattern in both COI (Banco Chinchorro $=0.15$, Isla Cozumel $=0.13$ and Arrecife Alacranes $=0.11$ ) and Cyt-b (Banco Chinchorro $=0.0098$, Isla Cozumel $=0.0094$ and Arrecife Alacranes $=0.0078$ ).

The COI-RFLP analysis, based on the digestions of HaeIII, HpaII, and BstEII showed three, four and two haplotypes, respectively. A total of 13 composite haplotypes were formed, of which the dominant ones (AAA and $\mathrm{AAB}$ ) were the same in the three locations (Table 1). Cyt-b had at least ten polymorphic sites and 28

TABLE 1

Haplotype frequencies at three geographical locations for Cyt-b sequences (above) and COI-RFLP (below) in the queen conch S. gigas

$\begin{array}{ccccc}\text { Haplotype } & \text { Total } & \text { Banco Chinchorro } & \text { Isla Cozumel } & \text { Arrecife Alacranes } \\ \text { N } & 80 & 23 & 26 & 31 \\ \text { Hap 06 } & 20 & 0.174 & 0.269 & 0.290 \\ \text { Hap 01 } & 12 & 0.174 & 0.077 & 0.194 \\ \text { Hap 13 } & 8 & 0.087 & 0.154 & 0.065 \\ \text { Hap 08 } & 8 & 0.043 & 0.115 & 0.129 \\ \text { Hap 14 } & 4 & 0.087 & 0.038 & 0.032 \\ \text { Hap 16 } & 4 & - & 0.077 & 0.065 \\ \text { Hap 19 } & 2 & - & 0.038 & 0.032 \\ \text { Hap 04 } & 2 & 0.043 & - & 0.032 \\ \text { Hap 10 } & 1 & 0.043 & - & - \\ \text { Hap 11 } & 1 & 0.043 & - & - \\ \text { Hap 12 } & 1 & 0.043 & - & - \\ \text { Hap 15 } & 1 & 0.043 & - & 0.032 \\ \text { Hap 17 } & 1 & - & - & 0.032 \\ \text { Hap 18 } & 1 & - & - & - \\ \text { Hap 02 } & 1 & 0.043 & - & 0.032 \\ \text { Hap 20 } & 1 & - & & -\end{array}$


TABLE 1 (Continued)

Haplotype frequencies at three geographical locations for Cyt-b sequences (above) and COI-RFLP (below) in the queen conch $S$. gigas

\begin{tabular}{|c|c|c|c|c|}
\hline Haplotype & Total & Banco Chinchorro & Isla Cozumel & Arrecife Alacranes \\
\hline Hap 21 & 1 & - & - & 0.032 \\
\hline Hap 22 & 1 & - & - & 0.032 \\
\hline Hap 23 & 1 & - & 0.038 & - \\
\hline Hap 24 & 1 & - & 0.038 & - \\
\hline Hap 25 & 1 & - & 0.038 & - \\
\hline Hap 26 & 1 & - & 0.038 & - \\
\hline Hap 27 & 1 & - & 0.038 & - \\
\hline Hap 28 & 1 & - & 0.038 & - \\
\hline Hap 03 & 1 & 0.043 & - & - \\
\hline Hap 05 & 1 & 0.043 & - & - \\
\hline Hap 07 & 1 & 0.043 & - & - \\
\hline Hap 09 & 1 & 0.043 & - & - \\
\hline Total & 28 & 15 & 13 & 13 \\
\hline \multicolumn{5}{|c|}{ Composite haplotype ${ }^{a}$} \\
\hline $\mathrm{N}$ & 155 & 50 & 40 & 65 \\
\hline AAA & 90 & 0.50 & 0.58 & 0.65 \\
\hline $\mathrm{AAB}$ & 37 & 0.32 & 0.25 & 0.17 \\
\hline $\mathrm{ABA}$ & 3 & 0.02 & 0.03 & 0.02 \\
\hline ACA & 7 & 0.06 & 0.03 & 0.05 \\
\hline $\mathrm{ABB}$ & 3 & 0.02 & - & 0.03 \\
\hline BAA & 5 & - & 0.03 & 0.06 \\
\hline BAB & 1 & 0.02 & - & - \\
\hline CAA & 1 & - & - & 0.02 \\
\hline $\mathrm{CBA}$ & 4 & 0.02 & 0.05 & 0.02 \\
\hline $\mathrm{ADA}$ & 1 & - & 0.03 & - \\
\hline BBA & 1 & - & 0.03 & - \\
\hline CBB & 1 & 0.02 & - & - \\
\hline BDA & 1 & 0.02 & - & - \\
\hline Total & 13 & 9 & 8 & 8 \\
\hline
\end{tabular}

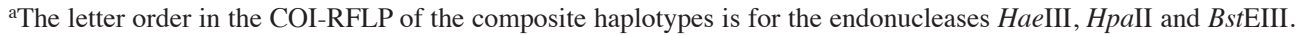
$\mathrm{N}$ : Sample size.
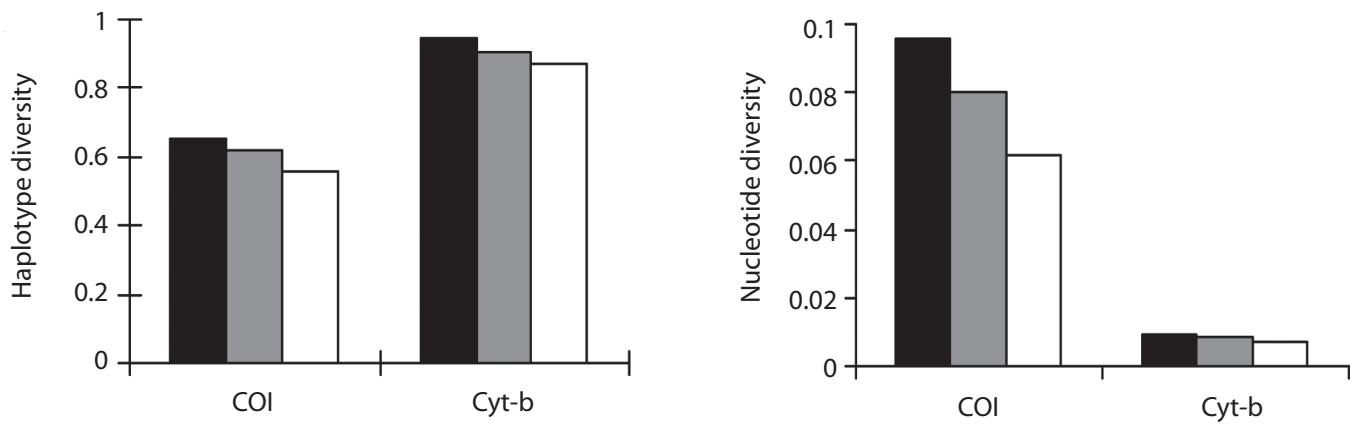

Fig. 1. COI and Cytb genetic diversity of Strombus gigas at three locations in the Mexican Caribbean (left panel: haplotypic diversity; right panel: nucleotidic diversity). Banco Chinchorro (black), Isla Cozumel (grey) and Arrecife Alacranes (white). 
different sequences. The main haplotypes (Hap 06, Hap 01, Hap 13 and Hap 08) were also shared by the three locations (Table 1). Exclusive haplotypes were observed for Cyt-b and $\mathrm{COI}$, but their frequencies were, in all cases, always less than 5\% (Table 1).

No statistically significant heterogeneity in the distribution of haplotypes among locations was revealed (COI: $\chi^{2}=23.79, \mathrm{p}=0.49$; Cyt-b: $\left.\chi^{2}=51.5, \mathrm{p}=0.734\right)$. The genetic divergence analyses (AMOVA) based on RFLP with COI $\left(F_{S T}=0.005, \mathrm{p}=0.247\right)$ and Cyt-b sequences $\left(F_{S T}=0.019, \mathrm{p}=0.161\right)$, did not show significant differences among locations indicating genetic homogeneity among them. Significant pairwise differences were neither observed (Table 2). Nevertheless, a marginal pairwise $F_{S T}$ between Banco Chinchorro and Arrecife Alacranes was found and the frequencies of the

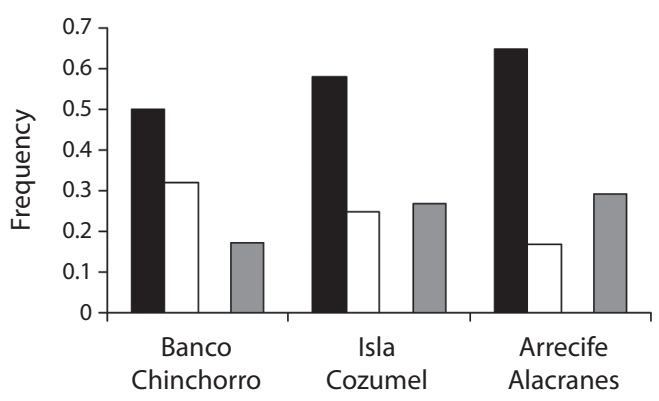

Fig. 2. Main haplotype frequencies of the queen conch Strombus gigas. Black and white are COI haplotypes (AAA and $\mathrm{AAB}$, respectively); grey is the Cyt-b haplotype (Hap 06). main haplotypes of both genes showed a slight increasing/decreasing cline pattern from Banco Chinchorro to Arrecife Alacranes (Fig. 2).

The Cyt-b sequence alignment of 447-bp fragments resulted in a Maximum Parsimony Network tree in which individuals from the three locations shared clades (Fig. 3) and thus there were no particular clades associated with any of the geographical locations. Nevertheless, the isolation by distance analysis showed a strong correlation between geographic and genetic distances $\left(r^{2}=0.87\right)$, a pattern also observed in the genetic distance, represented by the pairwise $F_{S T}$, which shows Isla Cozumel intermediate between the other two locations (Table 2).

The sudden expansion model fitted the mismatch distributions for the three sites ( $\mathrm{SSD}=0.016, \mathrm{p}=0.40$ for Banco Chinchorro; $\mathrm{SSD}=0.011, \mathrm{p}=0.41$ for Isla Cozumel; $\mathrm{SSD}=0.014, \mathrm{p}=0.48$ for Arrecife Alacranes (Fig. 4 ), suggesting that the hypothesis of a sudden population expansion cannot not be rejected.

\section{DISCUSSION}

Genetic diversity: In spite of the endangered status of the queen conch, the overall genetic diversity in the COI and Cyt-b genes varied from medium to high values, suggesting that $S$. gigas has not reached genetically threatened levels, as would be expected if a serious bottleneck would had happened. Examples of decrease in genetic diversity after severe

TABLE 2

Queen conch S. gigas pairwise population comparisons of Cyt-b sequences (left) and COI-RFLP (right).

$\mathrm{F}_{\mathrm{ST}}$ and their respective $\mathrm{p}$ values are below and above the matrix, respectively

\begin{tabular}{lcccccc} 
& \multicolumn{3}{c}{ COI } & \multicolumn{3}{c}{ Cyt-b } \\
& $\begin{array}{c}\text { Banco } \\
\text { Chinchorro }\end{array}$ & $\begin{array}{c}\text { Isla } \\
\text { Cozumel }\end{array}$ & $\begin{array}{c}\text { Arrecife } \\
\text { Alacranes }\end{array}$ & $\begin{array}{c}\text { Banco } \\
\text { Chinchorro }\end{array}$ & $\begin{array}{c}\text { Isla } \\
\text { Cozumel }\end{array}$ & $\begin{array}{c}\text { Arrecife } \\
\text { Alacranes }\end{array}$ \\
Banco Chinchorro & - & 0.6 & $0.045^{*}$ & - & 0.243 & 0.054 \\
Isla Cozumel & -0.00618 & - & 0.563 & 0.00969 & - & 0.694 \\
Arrecife Alacranes & 0.01402 & -0.00343 & - & 0.05957 & -0.01287 & -
\end{tabular}

*non-significant after Bonferroni sequential correction. 


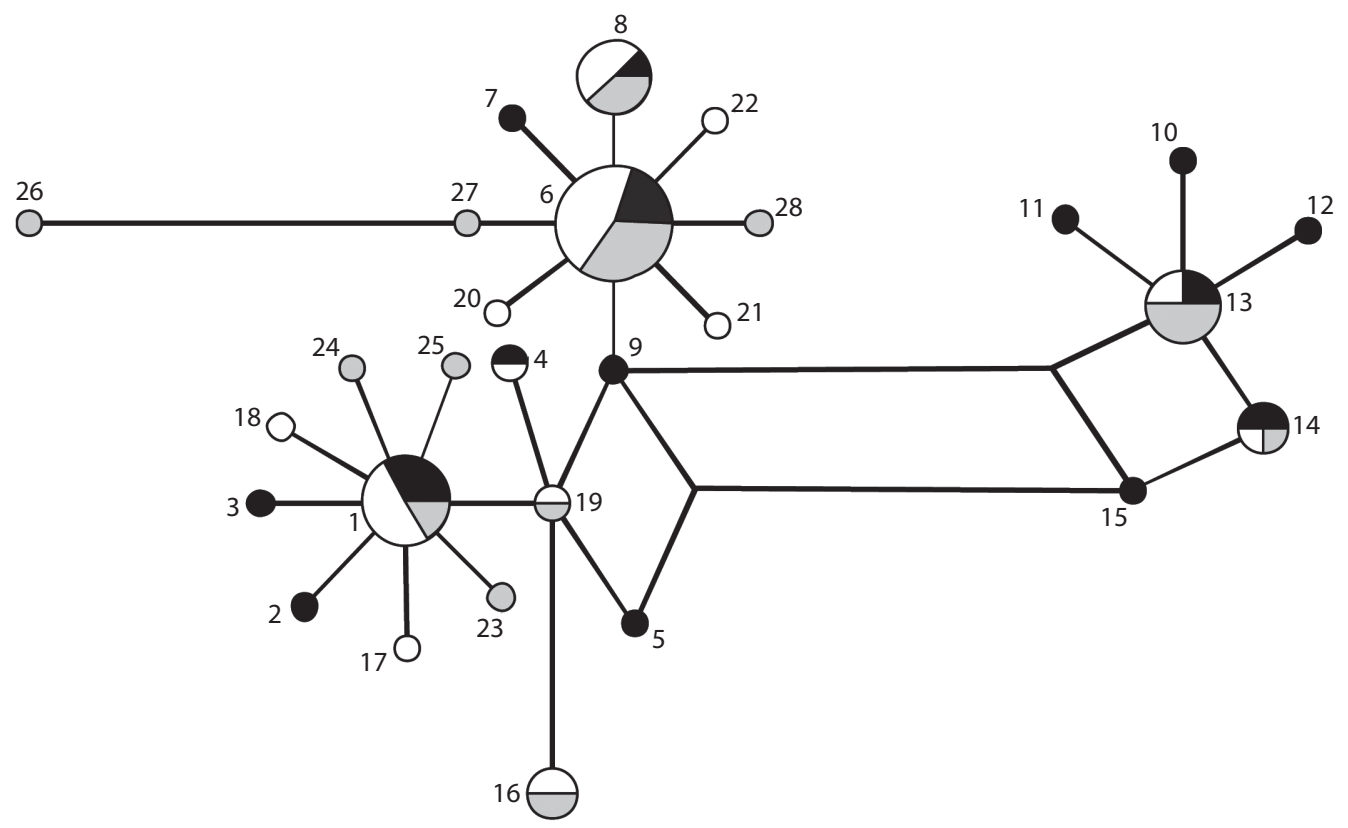

Fig. 3. Maximum Parsimony Network of specimens from three localities based on Cyt-b sequences: Banco Chinchorro (black), Isla Cozumel (grey) and Arrecife Alacranes (white). Each circle indicates an haplotype, its size indicates the number of specimens containing the haplotype, and the longitude of the line is the genetics distance between them.

bottlenecks have been documented in the Northern Elephant Seal (Hoelzel et al. 2002) and the Hungarian Meadow Viper (Újvári et al. 2002).

The higher genetic diversity and $\mathrm{Nd} / \mathrm{Hd}$ proportion found at Banco Chinchorro suggests that these locations have older and larger populations because more time is needed to produce more divergent haplotypes. This is supported by the analysis of the demographic history based on Cyt-b, in which Banco Chinchorro shows a right-shifted unimodal mismatch distribution that suggests that this location may be relatively older than the other sites (Rogers \& Harpending 1992). A less unimodal pattern in Banco Chinchorro may also indicate a historically more stable population than the other sites, presumably as a consequence of being less environmentally impacted. These results and the lack of evidence of a genetic bottleneck at Arrecife Alacranes, suggest that the slightly lower genetic diversity may be due to a historic lower population size, rather than an intensive overexploitation activity.

Genetic differentiation: While the lack of a significant genetic subdivision among the three locations suggests that gene flow is present, the cline from South to North in genetic diversity and haplotype frequencies; the marginal pairwise $F_{S T}$ between Banco Chinchorro and Arrecife Alacranes suggests that gene flow between these extreme positions might be somewhat reduced. Similar results were reported by Tello-Cetina et al. (2005), who, based on allozymes, stated that the samples from Arrecife Alacranes were less related to sites in the Mexican Caribbean. Furthermore, the genetic distance dendrogram and the correlation between genetic and geographic distances suggest that queen conch population follows a pattern of raising genetic differences as the 

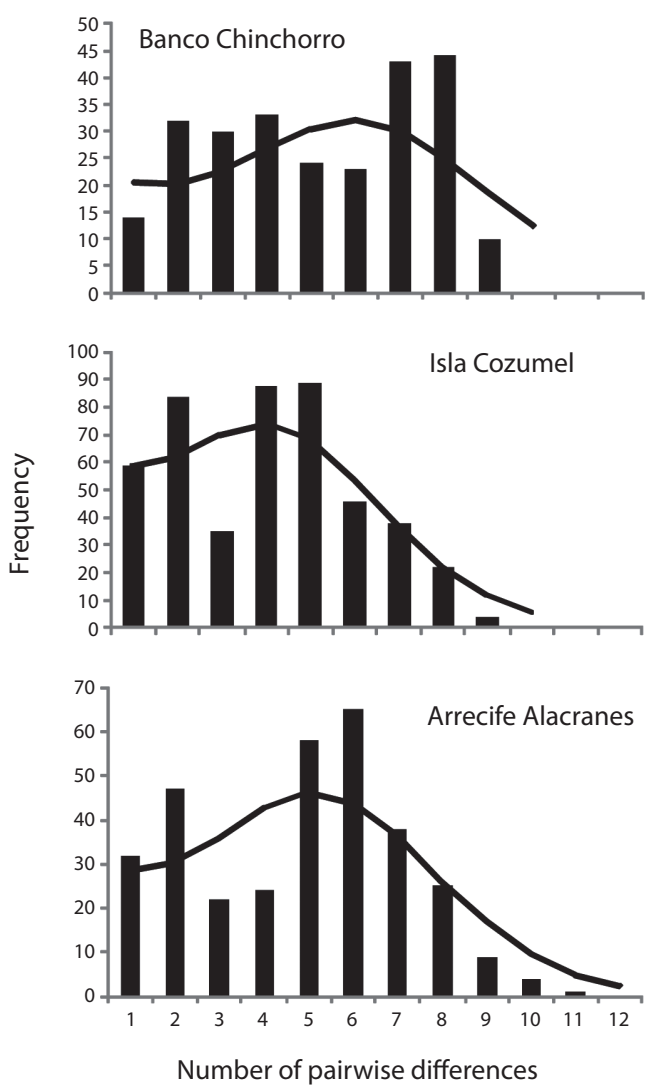

Fig. 4. Mismatch distribution from the Cyt-b for the three localities. Bars represent observed distribution and lines represent expected distribution according to the sudden expansion model.

geographical distance increases, similar to the isolation-by-distance model (Wright 1943).

An alternative explanation to the marginal $F_{S T}$ differences between Banco Chinchorro and Arrecife Alacranes comes from the mismatch distribution patterns, which suggest relatively distinct historical events. Thus, each location might have reappeared from isolation from low population sizes with some levels of recent gene flow between them.

A South to North gene flow pattern is supported by the oceanographic data. Cetina et al. (2006) reported that the current runs Northeastward parallel to the coast, from Banco Chinchorro to Isla Cozumel. This current has its origin in Central America, from the Cayman Current that flows Eastwards, arriving close to the middle of Yucatan Peninsula. At Banco Chinchorro, there are reversal episodes on which the current flows Southward (Cetina et al. 2006). Therefore, it is probable that larval dispersal along the East coast of the Yucatan Peninsula would be from Banco Chinchorro to Isla Cozumel, rather than the opposite. After the Isla Cozumel, the current intensifies as it passes through the Yucatan Channel and forms two streams, one stream flowing toward Florida and the Atlantic, and the other flowing Westward into the Gulf of Mexico. While the first stream would be transporting larvae from Isla Cozumel to Florida, the second stream would be dispersing the larvae from Isla Cozumel to Arrecife Alacranes. Little transport would be expected in the opposite direction.

However, if current direction varies in the first few meters of the water column, as it appears from surface current maps (Gyory et al. 2010; Fig. 5), then larval vertical distribution could be having an enormous effect on the direction of the dispersal. Barile et al. (1994) reported that at early stages, queen conch veliger larvae show positive phototaxis concentrating in the surface, but that more aged larvae (16-37 day) does not necessarily concentrates in the surface, and thus might be dispersed by deeper water currents. Therefore, these larvae might have a greater chance to be transported Northwards, but very weakly Eastwards (i.e. to Arrecife Alacranes).

Studies of reef species from the Caribbean Sea have also shown contrasting results. Vollmer \& Palumbi (2007) found a genetic population structure caused by limited larval dispersal in the staghorn coral Acropora cervicornis. Purcell et al. (2006) found that the gene flow pattern in two reef fish species (French grunt Haemulon flavolineatum and bluehead wrasse Thalassoma bifasciatum) was highly dependant on the planktonic larval stage duration. They found an isolation-by-distance genetic structure pattern in $H$. flavolineatum (larval period $\sim 15$ days) and a lack of a genetic structure pattern in T. bifasciatum (larval period 

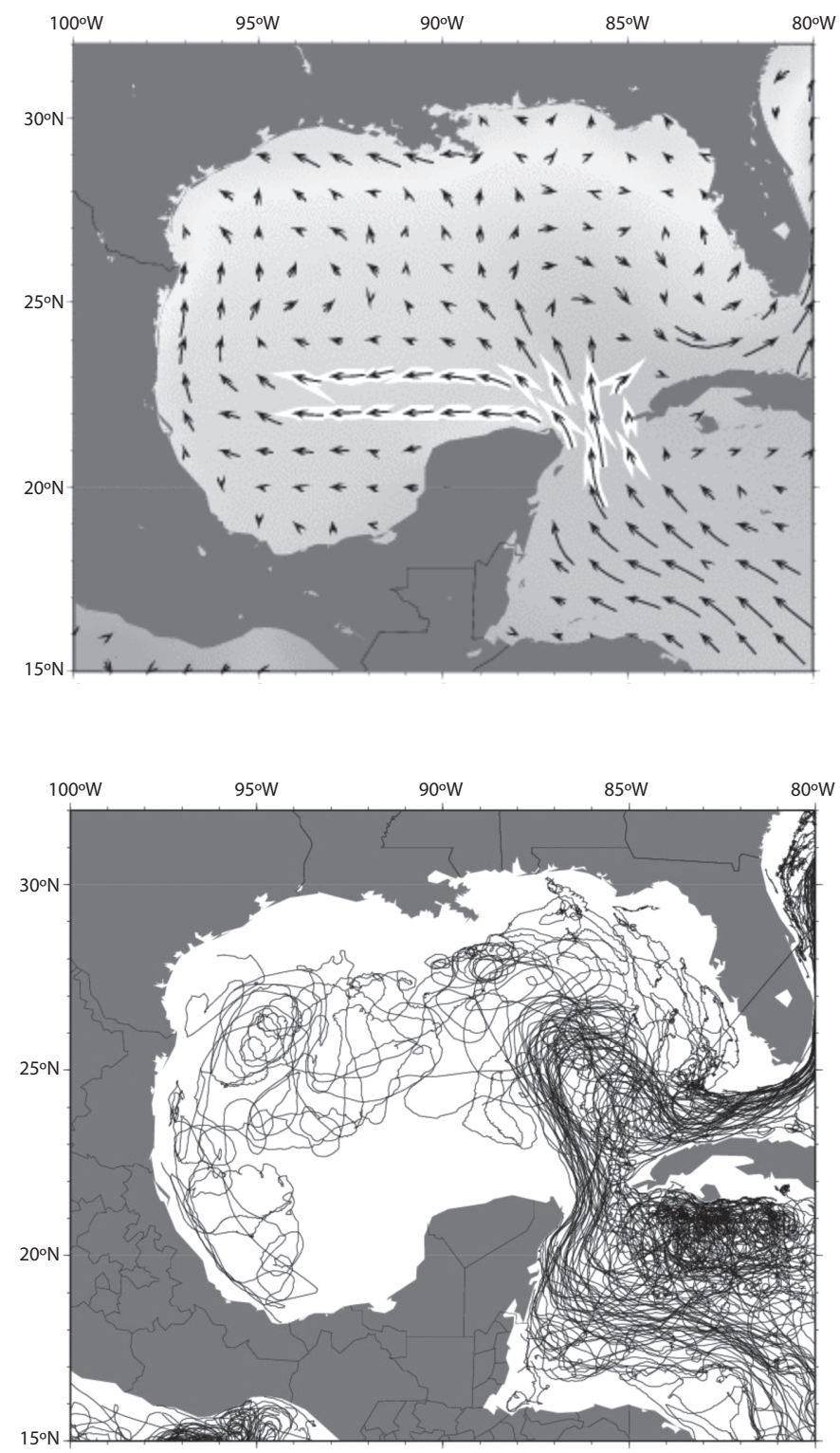

Fig. 5. Surface currents of the Yucatan Current. Above: Mariano Global Surface Velocity Analysis (MGSVA) map shows surface current patterns at 1 degree longitude and latitude resolution; below: satellite $15 \mathrm{~m}$ depth drifting buoys tracks. Figures taken from http://oceancurrents.rsmas.miami.edu/caribbean/mexican_2.html with the permission of the author (A.J. Mariano).

$\sim 45$ days). In the trochid gastropod Cittarium pica Díaz-Ferguson et al. (2010) found that the patterns of genetic differentiation are associated with larger geographical scales, and a partial correspondence with other studies of connectivity based on larval dispersal and hydrodynamic models.

Implications for management practices: In those species in which gene flow is restricted 
by hundreds of kilometers, such as the Staghorn coral, long-distance dispersal of larvae cannot be relied as a practical conservation tool for population recovery; thus, local protective actions must be practiced (Vollmer \& Palumbi 2007). This is also true like the French grunt, which shows an isolation-by-distance pattern.

The lack of genetic structure of the queen conch along the Yucatán coast suggests a management on a single panmictic population basis. However, based on the evidence of a weak cline in genetic diversity and haplotype frequencies, the process of self-sustaining in the sampled populations might be more important in the short term. From a study of dispersal and distribution of queen conch veliger larvae, Aldana-Aranda \& Perez-Perez (2007) suggested that most of the larvae is produced and retained within the Arrecife Alacranes, but some larvae is carried Northward. The status of Arrecife Alacranes as national park (http:// www.conanp.gob.mx/sinap.html) in which primary production activities (i.e. fisheries) are not allowed should be maintained to promote auto-replenishment of the local population (Anonymous 1988).

Isla Cozumel and the surrounding area, of high intensity tourism, would require additional actions to recover overexploited beds. Stock enhancement, either by releasing hatchery-reared larvae or by translocating juveniles or adults, has been proposed for this purpose. Delgado et al. (2004) suggested that translocation would be a more cost-effective strategy. In both cases, care is needed to avoid unwanted genetic effects (Bell et al. 2005).

The case of Banco Chinchorro (http:// www.conanp.gob.mx/sinap.html) as a biosphere reserve, and where controlled extraction activities are allowed (Anonymous 1988), would not have threats on its population genetic diversity, because this area seems to be a self-sustainable site that might receive larvae from other areas of the Caribbean.

In all cases, close surveillance is needed to reduce illegal fishing that takes place in Mexico and other areas of the Caribbean (Theile 2005). Studies of dispersal and connectivity of queen conch larvae over short distances are also needed for a better understanding of recovering capacity in depleted areas.

\section{ACKNOWLEDGMENTS}

The authors are grateful to Donaldo Martínez, Pedro Cadena, Keneth Cervera and Juan Carlos Espinoza (INAPESCA), the fishermen cooperatives 'SCPP Pescadores de Banco Chinchorro', and 'SCPP Isla Cozumel', the Banco Chinchorro Biosphere Reserve and the Mexican Army vessel 'Progreso'. Samples were collected with permit DGOPA/8427/220904/4043 from CONAPESCA. This research was funded by a SAGARPA-CONACYT grant (no.2002-001-1530) to Claudia Padilla.

\section{RESUMEN}

El caracol rosado Strombus gigas es una especie amenzada en México y otros sitios del Caribe. Su conservación a largo plazo requiere la comprensión de la conectividad entre sus poblaciones. En este estudio se evaluó la diversidad y diferenciación genética de muestras recolectadas en tres sitios del Caribe y Golfo de México adyacentes a la Península de Yucatán. Las muestras se obtuvieron de la captura comercial en Banco Chinchorro $(n=50)$ e Isla Cozumel $(n=40)$ en marzo de 2004. En noviembre de 2004 se obtuvieron muestras de Arrecife Alacranes $(n=65)$ de animales vivos, mediante un método no invasivo diseñado para la obtención de hemolinfa; los organismos muestreados se liberaron de vuelta al medio natural. Se analizó la diversidad genética de dos genes del ADN mitocondrial (COI y Cyt-b). La diversidad genética en las tres localidades varió entre 0.55 - 0.65 en COI y 0.87 - 0.94 en Cyt-b no indicando reducción por cuello de bote1la. Un índice de fijación no significativamente diferente de cero $\left(F_{S T}=0.019, \mathrm{p}=0.161\right)$ y un árbol en Red de Máxima Parsimonia que no mostró clados particulares asociados con localidades específicas, sugiere que no hay diferencias genéticas significativas entre sitios. Sin embargo, los patrones clinales observados en la diversidad genética y en las frecuencias haplotípicas, así como la mayor distancia genética registrada entre las localidades más alejadas (Banco Chinchorro y Arrecife Alacranes) sugiere un posible un patrón de aislamiento por distancia. Se discute el papel de los sistemas de corrientes principales del Caribe mexicano sobre la posible diferenciación genética de $S$. gigas. Asimismo, se discute el manejo de las localidades estudiadas como unidades discretas. 
Palabras clave: estructura genética, Strombus gigas, ADN mitocondrial, aislamiento por distancia, Mar Caribe, conectividad.

\section{REFERENCES}

Aldana-Aranda, D. \& M. Perez-Perez. 2007. Abundance and distribution of queen conch (Strombus gigas, Linne 1758) veligers of Alacranes Reef, Yucatán, México. J. Shellfish Res. 26: 59-63.

Anonymous. 1988. Ley General del Equilibrio Ecológico y La Protección al Ambiente. Secretaria del Medio Ambiente y Recursos Naturales, SEMARNAT. Diario Oficial de la Federación, 28 de enero de 1988, México.

Anonymous. 2006. ACUERDO mediante el cual se aprueba la actualización de la Carta Nacional Pesquera. Diario Oficial de la Federación, 25 de agosto de 2006, México

Barile, P.J., A.W. Stoner \& C.M. Young. 1994. Phototaxis and vertical migration of the queen conch (Strombus gigas Linne) veliger larvae. J. Exp. Mar. Biol. Ecol. 183: $147-162$.

Beaumont, A. 2000. Genetic considerations in transfer and introductions of scallops. Aquaculture Int. 8: 493-512.

Bell, J.D., P.C. Rothlisberg, J.L. Munro, N.R. Loneragan, W.J. Nash, R.D. Ward \& N.L. Andrew. 2005. Restocking and stock enhancement of marine invertebrate fisheries. Advances in Marine Biology 49. Academic, California, USA.

Bohonak, A.J. 2002. IBD (Isolation by Distance): a program for analyses of isolation by distance. J. Hered. 93: $153-154$

Campton, D.E., C.J. Berg Jr., L.M. Robinson \& R.A. Glazer. 1992. Genetic patchiness among populations of queen conch Strombus gigas in the Florida Keys and Bimini. Fish. Bull. 90: 250-259.

Cetina, P., J. Candela, J. Sheinbaum, J. Ochoa \& A. Badan. 2006. Circulation along the Mexican Caribbean coast. J. Geophys. Res. 111 C08021: 1-19.

CITES. 1973. Convention on International Trade in Endangered Species of Wild Fauna and Flora. Appendix II (valid from 1 July 2008). (Downloaded: November 25, 2010, www.cites.org/eng/app/E-Ju101.pdf).

CONAPESCA. 2010. Anuario Estadístico de Acuacultura y Pesca 2008. Comisión Nacional de Acuacultura y Pesca. Mazatlán, Sinaloa, México. (Downloaded: November 25, 2010, www.sagarpa.gob.mx/conapes$\mathrm{ca} /$ planeacion/planeacionindx.htm).
Delgado, G.A., C.T. Bartels, R.A. Glazer, N.J. BrownPeterson \& K.J. McCarthy. 2004. Translocation as a strategy to rehabilitate the queen conch (Strombus gigas) population in the Florida Keys. Fish. Bull. 102: 278-288.

Diaz-Ferguson, E., R. Haney, J. Wares \& B. Silliman. 2010. Population genetics of a Trochid gastropod broadens picture of Caribbean Sea connectivity. PLos ONE 5: e12675.

Excoffier, L., G. Laval \& S. Schneider. 2005. Arlequin ver. 3.0: An integrated software package for population genetics data analysis. Evolutionary Bioinformatics Online 1: 47-50.

FAO. 1993. Report of the Expert Consultation on utilization and conservation of aquatic genetic resources. FAO Fish. Rep. 491: 1-58.

Felsenstein, J. 1993. PHYLIP (Phylogeny Inference Package, Version 3. 5), Department of Genetics, University of Washington, Seattle, Washington, USA.

Folmer, O., M. Black, W. Hoeh, R. Lutz \& R. Vriejenhoek. 1994. DNA primers for amplification of mitochondrial cytochrome c oxidase subunit I from diverse metazoan invertebrates. Mol. Mar. Biol. Biotechnol. 3: 294-299.

Gore, S. \& A. Llewellyn. 2005. Distribution and abundance of Strombus gigas in the British Virgin Islands. Proc. Gulf Carib. Fish. Inst. 56: 697-704.

Gyory, J., A.J. Mariano \& H.R. Edward. 2010. "The Mexican Current" (Downloaded: November 25, 2010, http://oceancurrents.rsmas.miami.edu/caribbean/ mexican.html)

Hernandez, E. 2008. Crime scene investigation of recent illegal shore-based recreational fishing activity on Queen Conch (Strombus gigas) in Culebra Island, Puerto Rico. Proc. Gulf Carib. Fish. Inst. 60: 648.

Hoelzel, A.R., R.C. Fleischer, C. Campagna, B.J. Le Boeuf \& G. Alvord. 2002. Impact of a population bottleneck on symmetry and genetic diversity in the northern elephant seal. J. Evol. Biol. 15: 567-575.

Mateo, J. \& J.C. Tejeda. 2008. The queen conch, Strombus gigas, resource in the Dominican Republic. Proc. Gulf Carib. Fish. Inst. 60: 519-524.

McElroy, D., P. Moran, E. Bermingham \& I. Kornfield. 1992. REAP: an integrated environment for the manipulation and phylogenetic analysis of restriction data. J. Hered. 83: 157-158. 
Mitton, J.B., C.J. Berg Jr \& K.S. Orr. 1989. Population structure, larval dispersal, and gene flow in the queen conch, Strombus gigas, of the Caribbean. Biol. Bull. 177: $356-362$

Morales, F. 2004. Metapopulation structure of the queen conch, Strombus gigas (Linne, 1758) throughout the Intra-Americas Sea. Diss. Abst. Int. Pt. B.-Sci. and Eng. 65: 597-598

Morales, F.E. \& J. Lopez. 2003. Análisis genético del botuto Queen Conch (Strombus gigas Linne, 1758): resultados preliminares, p. 15-20. In D. Aldana-Aranda (ed.). El caracol Strombus gigas: conocimiento integral para su manejo sustentable en el Caribe, CYTED, Programa Iberoamericano de Ciencia y Tecnología para el Desarrollo, Yucatán, México.

Neiman, M. \& C.M. Lively. 2004. Pleistocene glaciation is implicated in the phylogeographical structure of Potamopyrgus antipodarum, a New Zealand snail. Mol. Ecol. 13: 3085-3098.

Oxenford, H.A., A. Fields, C. Taylor \& D. Catlyn. 2008. The little-known conch (Strombus gigas) fishery of Barbados. Proc. Gulf Carib. Fish. Inst. 60: 125-136.

Page, R.D.M. 1996. TREEVIEW: An application to display phylogenetic trees on personal computers. Comp. Appl. Biosci. 12: 357-358.

Perez-Ruzafa, A., M. Gonzalez-Wanguemert, P. Lenfant, C. Marcos \& J.A. García-Charton. 2006. Effects of fishing protection on the genetic structure of fish populations. Biol. Conserv. 129: 244-255.

Purcell, J.F.H., R.K. Cowen, C.R. Hughes \& D.A. Williams 2006. Weak genetic structure indicates strong dispersal limits: a tale of two coral reef fish. Proc. Royal Soc. B. 273: 1483-1490.

Roff, D.A. \& P. Bentzen. 1989. The statistical analysis of mitochondrial DNA polymorphisms: $\mathrm{X}^{2}$ and the problem of small samples. Mol. Biol. Evol. 6: 539-545.

Rogers, A.R. \& H. Harpending. 1992. Population growth makes waves in the distribution of pairwise genetic differences. Mol. Biol. Evol. 9: 552-569.

Rozen, S. \& H. Skaletsky. 2000. Primer3 on the WWW for general users and for biologist programmers, p. 365386. In S. Krawetz \& S. Misener (eds.). Bioinformatics methods and protocols: methods in molecular biology. Humana, Totowa, New Jersey, USA.

Rus, A., S.R. Santos \& C. Muir. 2010. Genetic population structure of an anchialine shrimp, Metabetaeus lohena (Crustacea: Alpheidae), in the Hawaiian Islands. Rev. Biol. Trop. 58: 159-170.
Ryman, N. \& F. Utter. 1987. Population genetics and fishery management. University of Washington, Seattle, Washington, USA.

Santos, S.R. 2006. Patterns of genetic connectivity among anchialine habitats: a case study of the endemic Hawaiian shrimp Halocaridina rubra on the island of Hawaii. Mol. Ecol. 15: 2699-2718.

Schweizer, D. \& J.M. Posada. 2006. Distribution, density, and abundance of the queen conch, Strombus gigas, in Los Roques Archipielago National Park, Venezuela. Bull. Mar. Sci. 79: 243-258.

Shulman, M. \& E. Bermingham. 1995. Early life histories, ocean currents, and the population genetics of Caribbean reef fishes. Evolution 49: 897-910.

Silberman, J.D., S.K. Sarver \& P.J. Walsh. 1994. Mitochondrial DNA variation and population structure in the spiny lobster Panulirus argus. Mar. Biol. 120: 601-608.

Sweijd, N.A., B.C.K. Bowie, A.L. Lopata, A.M. Marinaki, E.H. Harley \& P.A. Cook. 1998. A PCR technique for forensic, species-level identification of abalone tissue. J. Shellfish Res. 17: 889-895.

Tello-Cetina, J.A., L.A. Rodríguez-Gil \& F. RodríguezRomero. 2005. Population genetics of the pink snail Strombus gigas in the Yucatan Peninsula: Implications for its management and fishery. Cienc. Mar. 31: 379-386.

Theile, S. 2001. Queen conch fisheries and their management in the Caribbean. TRAFFIC, Europe.

Theile, S. 2005. Status of the queen conch Strombus gigas stocks, management and trade in the Caribbean: A CITES review. Proc. Gulf Carib. Fish. Inst. 56: 675-695.

Újvári, B., T. Madsen, T. Kotenko, M. Olsson, R. Shine \& H. Wittzell. 2002. Low genetic diversity threatens imminent extinction for the Hungarian meadow viper. Biol. Cons. 105: 127-130.

Vollmer, S.V. \& S.R. Palumbi. 2007. Restricted flow in the Caribbean staghorn coral Acropora cervicornis: Implications for recovery of endangered reefs. J. Hered. 98: 40-50.

Wright, S. 1943. Isolation by distance. Genetics 28: 114-138.

Yanick, J.F. \& D.D. Heath 2000. Survival and growth of mussels subsequent to hemolymph sampling for DNA. J. Shellfish Res. 19: 991-993. 